\title{
The Impact of Blockchain Technology in Higher Education Quality Improvement
}

\author{
Riya Widayanti ${ }^{1}$, Eka Purnama Harahap ${ }^{2}$, Ninda Lutfiani ${ }^{3}$, Fitra Putri Oganda ${ }^{4}$, Ita Sari Perbina Manik ${ }^{5}$ \\ ${ }^{1}$ Information System, Universitas Esa Unggul, Jakarta, 17214, Indonesia \\ 2,3,4,5 Informatic Engineering, Universitas Raharja, Tangerang, 15117, Indonesia
}

\section{ARTICLE INFO}

\section{Article history:}

Received May 13, 2021

Revised June 15, 2021

Accepted July 06, 2021

\section{Keywords:}

Blockchain; Higher Education; Impact;

Technology

\begin{abstract}
The times have made technology increasingly developed that there are innovations as new media to make it easier for humans in everyday life. Blockchain technology is an innovation that has been applied in various fields such as education, health, economy, and other areas. In this study, researchers want to see the impact that blockchain technology has had on universities in technology and information to improve universities' quality. The methodology used is by reviewing previous research papers related to the research. So that this research is expected to contribute, which can overcome the problems being faced, such as the application of blockchain in universities, namely how to use the blockchain system, what blockchain is, and how to change existing technology into disruptive technology. The experimental results state that by using data from the previous paper, the aim is to reveal the impact that blockchain technology has had on technology and information that is useful for improving the quality of universities in encouraging human potential and improving quality so that they can compete both domestically and abroad.
\end{abstract}

This work is licensed under a Creative Commons Attribution-Share Alike 4.0

Eka Purnama Harahap,

Universitas Raharja, Indonesia

Email: ekapurnamaharahap@ raharja.info

\section{INTRODUCTION}

Technology is a change that can see in every era. Changes in technology have become modern, affecting performance in every field such as education, health, economy, and all fields [1]. Changes in information and communication technology seen from the industrial revolution 1.0 to 4.0 always make changes every year, such as using more modern technology and under human needs to adapt to today's lifestyle, which is never separated from the name technology [2]. Nasution's research. M (2018) previously explained that information technology is a field of science with rapid development at any time, and it is impossible to predict any changes from the beginning of the year to the end of the year [3]. Patrick Ocheja, Brendan Flanagan, \& Hiroaki Ogata (2018) said that learning requires a technology that can visit educational activities without disturbing other activities [4].

In Fig. 1, the genesis block is the source for the creation of blockchain technology. Blockchain technology is a technology with popularity in education, becoming an icon in all fields. The privilege of blockchain is not far from the genesis block.

The background of the problem from the research conducted by Grigore albeanu (2017) explains how vital an online educational resource is for students because there are many places to find help. Knowledge (courses) is wasted on the platform because it doesn't run properly [5]. Blockchain technology is the right solution for online education. It can be developed into an application or in smart contacts, providing 
convenience as a platform for the world of education in conducting transactions, data storage, and data processing without fear of damage [6]. There are still problems that are often faced in online education, such as an assessment system that is not optimal in evaluating and the lack of digital certificate security that third parties can use. So to overcome this Junqi gou et al. provide solutions using technology blockchain [7]. Denia Falcao et al. said that learning methods in education require technology that can adapt to the times. The boundaries that hinder students from advancing in technological development need to be changed because blockchain technology is a technology that can be utilized and developed in all ways. Field to train students' abilities in terms of technology [8].

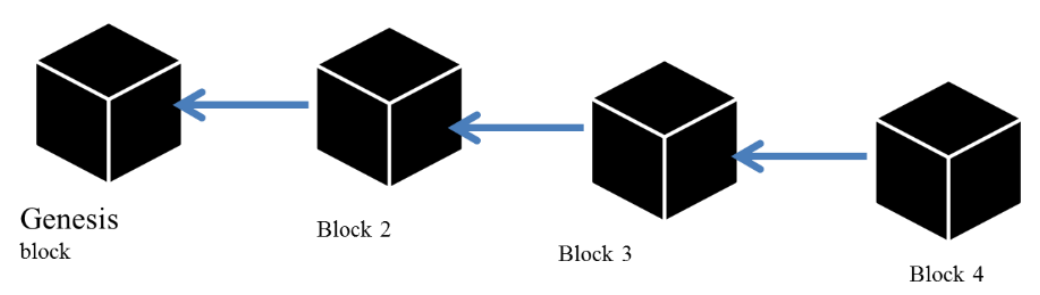

Fig. 1. Blockchain Genesis

Satoshi Nakamoto is the initiator of Blockchain in 2018 in cryptocurrency, used in health, voting, education, and others. The field of cryptocurrency education has become an innovation in problem control [9]. Blockchain is a ledger because it can store data from more than one transaction to be effective and verified [10]. In the communication process, nodes will confirm new blocks involving peer-to-peer networks in the system. The system records data on blocks but cannot be changed retroactively on blocks by requiring consensus on the web. Blockchain technology has decentralized, transparent, and immutable properties [11]. 1991 was the beginning of Stuart Haber and W. Scoot Stornetta's innovations in technology in a series of blocks with cryptography known today as part of blockchain technology [12]. This technology aims to apply a timestamp system model to documents to protect personal data so that other parties cannot damage it by copying data. Cryptographers in 1922 Bayer, Haber, and Stornetta incorporated the Merkle tree in a design that made in terms of quality improvement in terms of efficient collection capabilities in data processed in one block. It turns out that knew the history of the popular Blockchain in 2008 with the originator of Satoshi Nakamoto who tried to implement Blockchain in the core component of bitcoin or bitcoin care, which was called a tool in network transactions as a control center in data [13].

The urgency in this research is how universities can change the disrupted system from before by applying blockchain technology so that it helps work that has initially been manual in data processing can turn into automatic, decentralized data storage and provides work efficiency [14]. Harm other people, of course. So to prevent unwanted things, researchers want to contribute by proposing a blockchain technology that is applied in universities [15].

\section{LITERATURE REVIEW}

Technological changes are not far from the development of information and communication [16]. These can feel changes from the contact made in correspondence changes using the internet that is connected to a computer connected to a communication network [17]. Cyberspace is often said to communicate information in the global community or the world [18]. Communication technology develops through media in Whatsapp, social media, telephone, and others [19].

\subsection{Blockchain History}

The blockchain history is shown in Fig. 2. The development of blockchain from year to year has essential events such as in 2008 Satoshi Nakamoto sparked blockchain technology as a component of bitcoin. In 2009 the technology was developed as a valuable ledger as transactions in a network, with the development of blockchain technology known as blockchain 2.0. in 2014. The blockchain was used as a programming language in conducting transactions such as making transactions more straightforward for users to record with. Using smart contracts with automated system processes can issue receipts or invoices in payments between interested parties by sharing shareholder profits with smart contracts without third parties. And the development of blockchain technology in 2016 has been implemented in an automatic voting system. The company from IBM in Singapore has become an innovation as a research center [20].

Blockchain is a ledger with computer-processed data records that do not have a single entity (existence) that data blocks have security bound together with cryptographic principles (e.g. chains). Blockchain has a network that in the process is not authorized by the control center as (democratization) in the form of records 
in a ledger that can be shared or viewed without being able to change the data because the data is transparent [21]. With the performance of the blockchain already disrupting the industrial world, from here can see that blockchain technology does not have the authority or authority in it [22]. The blockchain performance process cannot be separated from the network in the form of a collection of bound nodes [23]. The computer can input data and provide output to its function [24]. A peer-to-peer network is a unique blockchain network with the primary function of peer-to-peer network sharing files with the term (torrent) [25]. We can explain briefly. Namely, this technology is a medium in conveying information between party one to party two delivered accurately and safely from the party conducting transactions in the blocking process [26]. The verified block has connected to the internet with thousands of computers and even millions of computers in the scattered chain, and there is a unique code [27].

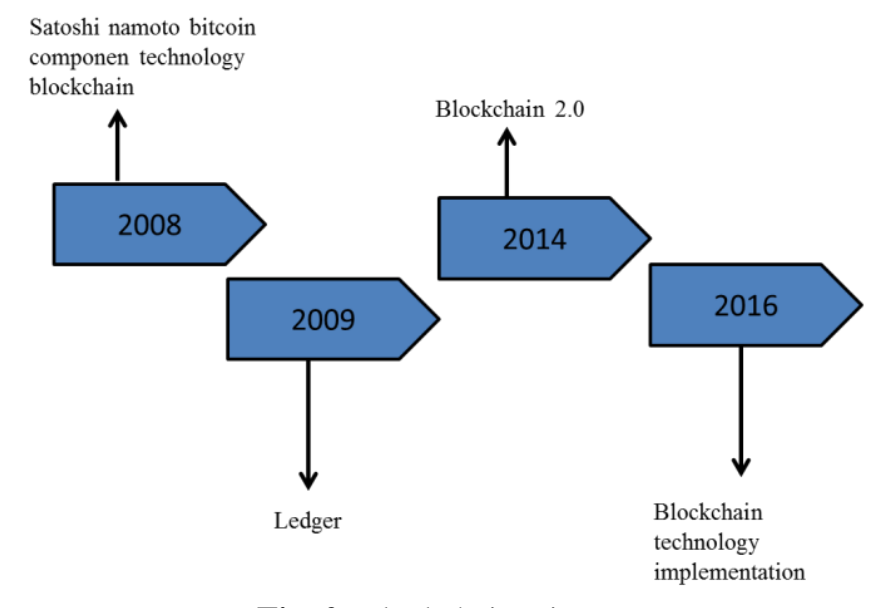

Fig. 2. Blockchain History

In addition, blockchain has three properties such as:

1. Open-source and Transparent

The meaning of open-source and transparent that is the code in the blockchain is open. Someone can access the code by verification in the code that is visible on the blockchain, but the accessor cannot change the data.

\section{Not centralized (decentralized)}

It is in the performance of the system no one controls. Because the blockchain code is not located in the servers operating the system, and the computers contain blocks with transactions in records on a system that is spread across thousands of computers.

\section{Eternal}

The eternal explanation of blockchain technology is the incoming data verified on blockchain technology will still exist and be the same. This means the data is infinite and will not be lost because the technology has collaborated with the hash pointer data to block and create a chain.

We can see that blockchain technology has impacted the education system and learning system [28]. Because of the (ACE Report), Ted Mitchell wrote a statement that there is a connected impact in the world of education and the workforce to create effectiveness and efficiency of technology in the research of [29]. The revealed that a system with digital-based rights management included in blockchain technology could be a solution in managing to record, storing, and digitally verifying certificates with guaranteed security [30]. The use of blockchain technology is often used in the field of change to digital form and distributing certificates in the world of education carried out by [31]. Blockchain is a system for recording transactions on computers with a decentralized peer-to-peer network in a connected environment without affecting third parties, thus bringing a technological improvement in terms of convenience, accuracy, data management, and security [32].

\subsection{Information and communication technology}

The progress of information and communication technology globally is increasing, including in Indonesia [33]. Information technology is known as data processing, data creation, and manipulating data into information, and communication technology is known as a tool in conveying information [34]. Because the use of information and communication technology can never be separated from everyday life such as 
transportation, health, education, and other fields [35], it can be seen that the technology applied in the field of education is increasingly modern because current needs must be adapted to the application in educational institutions, one of which is universities so that human resources can develop and not be left behind so that the quality of universities increases [36]. In educational institutions [37], the use of blockchain technology is already widespread in universities [38], not only in universities in one city [39] but has tried to be implemented in universities throughout Indonesia. Using blockchain technology is usually used as verification in certificates to maintain their authenticity [40]. The use of blockchain technology can be used in everything to verify credentials and be used as data processing needed in universities [41].

The utilization of information technology at every university is required to have innovation in providing services in offering convenience to its users [42]. One of them is at Raharja University, utilizing technology by implementing iDuHelp, which plays a role in overcoming complaints from students and lecturers at Raharja University. We will be given directions as to what to do in the next step. At IBI Darmajaya, this service is called E-Complaint [43], a medium for evaluating and detecting system weaknesses in universities. Not only that, in the field of communication, blockchain has been used in security and privacy for every user, one of which is intelligent devices at home [44]. For the application of technology, human resources are also needed who can apply technology [45]. Therefore training is necessary in its application to the parties concerned, such as training for lecturers in using new technology, a small example such as the certificate of lecturers who can teach e-learning at Raharja University [46].

\section{RESEARCH METHOD}

The place of research was conducted at Raharja University using the literature review method. The use of the Literature Review method is used to determine the impact of blockchain technology on improving universities. The research focused on how blockchain works in the previous paper. Fig. 3 is a research flow chart that has the following stages of implementation.

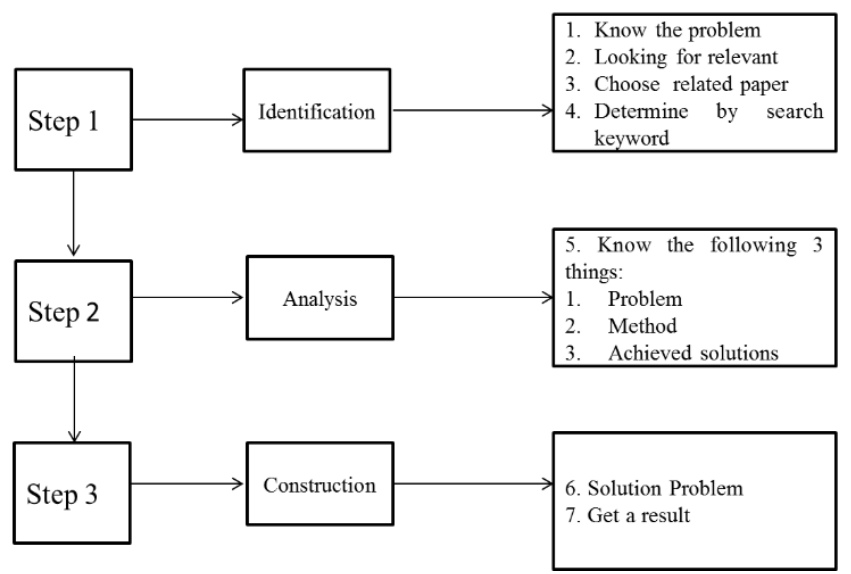

Fig. 3. Research Flowchart

There are stages of implementation:

1. Looking for papers related to the research theme discussed and in accordance with the research title.

2. Comparing previous papers regarding the problems faced by researchers and explaining solutions in solving problems.

3. Knowing the contribution of research in the application of blockchain in universities by surveying related papers.

In supporting this research, there are 10 results of the Literature Review from previous research papers that are shown in Fig. 4. Research conducted by Lukita, C. (2020) with the title "Implementation of a Content Copyright Data Collection System Using Blockchain" explains that blockchain technology can facilitate content data collection by procedures to secure created content and store original data. (original) from the creator. Not only that, universities in e-certificate systems often use the use of blockchain technology. The process of running the technology uses data based on the distribution of blockchain transactions by Yusuf, Muhamad, et al. (2019) entitled "Utilization of Technology Blockchain in Lecturer Certification Program." [47] and Winarno, Agus. (2019) research entitled "E-Transcript Design with Blockchain Technology." using blockchain with a blockchain system to design globally verified certificate e-transcripts with the aim of blockchain as a medium for issuing certificates that have verified blockchain technology [48]. Argani, Abhimanyu, and Wahyatma Taraka (2020) with the paper title "Utilizing Blockchain Technology to 
Optimize Certificate Security in Universities." Saying that can apply blockchain technology to certificates by using codes such as encryption, the parties' effect on the data becomes convenient because other people can copy the data and change the data cannot [49].

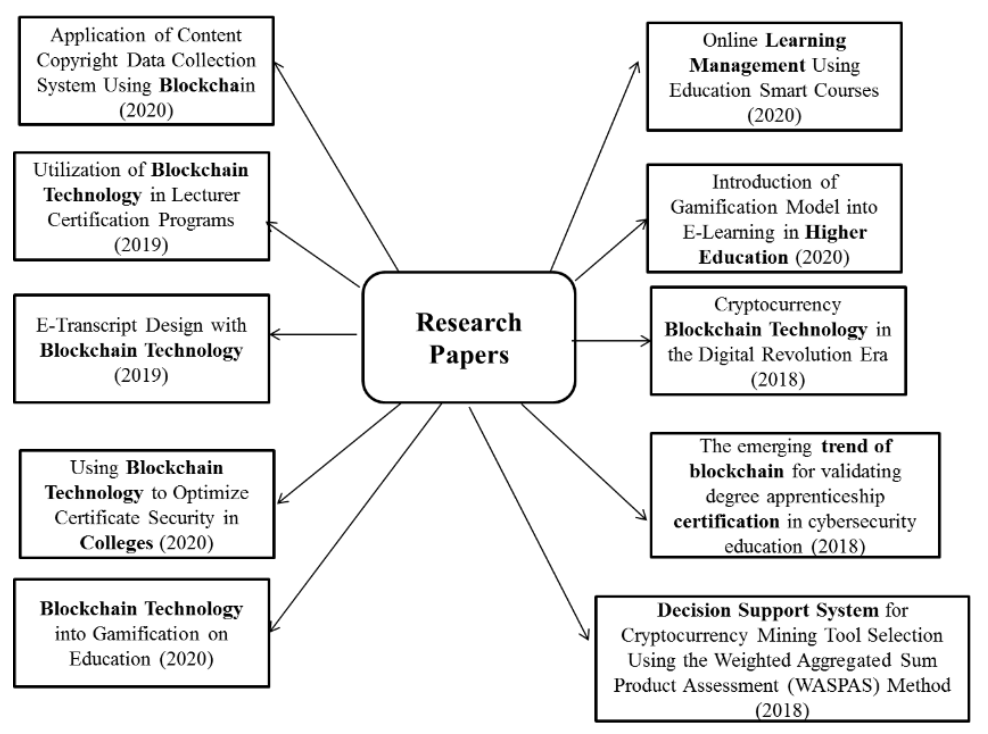

Fig. 4. Research papers

Research paper Aini, Qurotul et al. (2020), with the title "Blockchain Technology into Gamification on Education," said can change the current learning method in gamification that directs learning to be more fun. Contemporary, of course, like recent technological changes, the gamification method can be applied as a learning method in college high without exception [50]. Research conducted by Agustin, F., Oganda et al. (2020) entitled "Online Learning Management Using Education Smart Courses" discusses the paper wants to use smart courses as part of blockchain in overcoming problems that exist in the world of education in the form of gamification [51]. The gamification model system is growing and has been applied in e-learning in higher education brings innovations with positive impacts on students such as the learning process is not bored (happy in the running), more active in asking and answering questions found in Yainiaja, AK, et al.'s research. (2020) with the title "Introduction of Gamification Models into E-Learning in Higher Education" [52].

Bhiantara, Ida Bagus Prayoga (2018) with the paper title "Cryptocurrency Blockchain Technology in the Digital Revolution Era." Cryptocurrency is a transformative innovation that can overcome problems in the industrial sector, and over time cryptocurrency has been recognized by several fields to be applied [53]. Research conducted by the Airport, Indrachapa Buwaneka (2018), the title of the paper "The emerging trend of blockchain for validating degree apprenticeship certification in cybersecurity education" discusses education about blockchain technology that MSMEs have used, such as business developments that can compete in terms of data transactions becoming safer and simpler that way the performance process is not difficult [54] and the research conducted by Hermawan, Dikky. (2018) with the title "Decision Support System for the Selection of Cryptocurrency Mining Tools with the Weighted Aggregated Sum Product Assessment (WASPAS) Method" proves in the paper that the WASPAS method is one of the alternative methods with the proposed Qi value. We can conclude that the Q3 value is the best alternative with cryptocurrency mining tools, which have been applied by universities [55].

The construction of the ten research papers above is blockchain technology in the field of education, especially universities, bringing changes in technological systems in the field of data security, maintaining the authenticity of certificates, speed and accuracy in data transactions, and making innovations in the field of education while learning. So that in the future, it will have a positive impact on improving the quality of higher education [56].

\section{RESULT AND DISCUSSION}

Blockchain technology is increasing, and nowadays, of course, many efforts have been made. On 15 September 2018, CEO Pang Xue Kai introduced Tokocrypto to the public. The education carried out by CEO 
Pang Xue Kai was done by collaborating with several educational institutions, including Yogyakarta AMIKOM University, Indonesia Informatics and Business University (UNIBI) Bandung. However, the introduction of Tokocrypto continued to major cities in Indonesia, namely Makassar, Samarinda, Malang, Yogyakarta, Bandung, Jakarta, and Medan. Support in the application of blockchain technology is not enough from CEO Pang Xue Kai, because it takes help from the Government in introducing the public to new technology, namely blockchain [57]. The application of blockchain technology in education can be implemented because there are already human resources who understand implementing blockchain in universities. Education is a medium for humans to change the mindset of individuals to become more qualified in science. Therefore, the application of new technology or universities' current trend to quickly implement the technology is called Blockchain [58].

In Fig. 5, it can be seen how the blockchain works, starting from submitting data to make transactions run, the data enters blockchain technology with a network of nodes that function to connect data after the data is connected, the data will be validated to the data block that carries information from the previous block, after that one block will be connected to another block making information data safe through the blockchain chain after the transaction is complete.

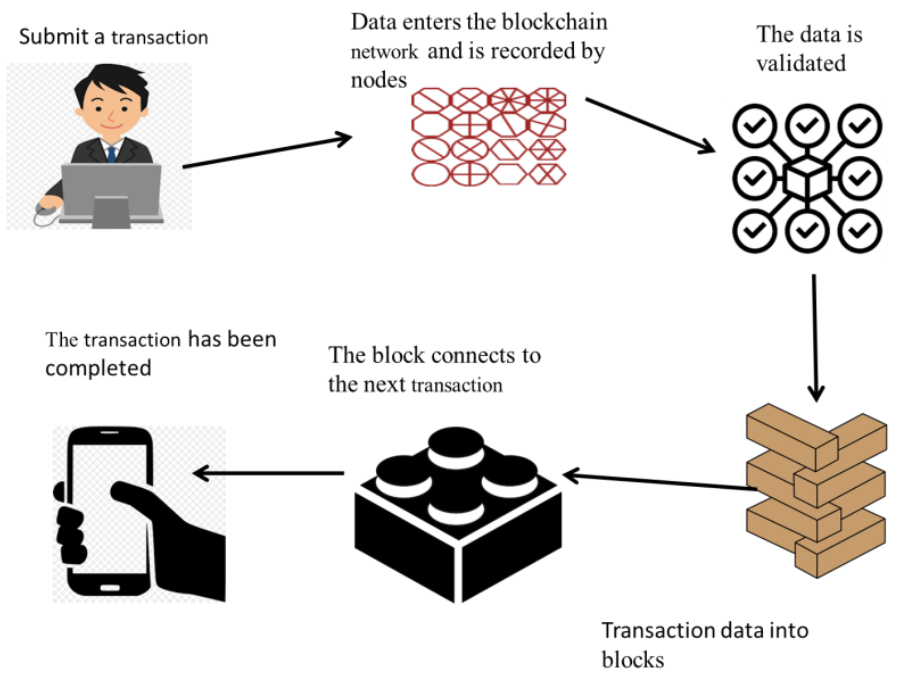

Fig. 5. How Blockchain works

The application of technology in universities also requires quality human resources to support existing resources. Many experts state that human resources are central in an educational institution such as a university in increasing creativity [59]. It can seem that the role of human resources is the essential thing needed as a medium for the application of new technology. Still, there are many obstacles in human resource management, such as (1) Technological and economic developments, (2) availability of quality labor, (3) occupation problems, and 4. organizational resources. Of the four issues, universities can develop human resources by doing service (tri dharma). In universities, resources with professional quality are called lecturers. Because lecturers are required to communicate verbally and in writing, be able to use information and communication technology, and be sensitive to changes from the outside world. Not only innovative in science such as doing the teaching, research, and dedication to lecturers [60].

Of the ten research papers in Fig. 4, there is a comparison of research methods using a literature review, for example, as done by with the title "Implementation of a Content Copyright Data Collection System Using Blockchain" says that blockchain can be used as a support system that can eliminate fraud in imitating data collection on Copyright. This research provides recommendations from the results of analysis, such as the impact of blockchain technology on universities, namely:

1. Application of blockchain-based certification in certificate issuance.

In certifying the certificate, the name blockchain technology is needed. The technology changes the work process that is usually done manually to modern so that the process is fast and precise. Certificates that have been certified are of higher quality so that people who are about to commit crimes cannot be executed. Raharja University is one of the universities that use blockchain technology in certificate certification. The 
certificate issued will not be problematic, and other parties who want to steal data from the university cannot because of the unique code that characterizes it.

In Fig. 6, it can be seen how the performance of blockchain technology in certificates. The first step of a certificate that has been printed from university into blockchain technology. Then, the data in the form of student information goes into the hash. The technology in the hash has performance like a block in the content of the data has formed with code unique. After passing it, the previous block's hash develops blockchain technology that already brings information from the block to be safe. That way, if a party wants to see the original student certificate or not, he can see the unique code in it without looking for data in the form of stacked papers.

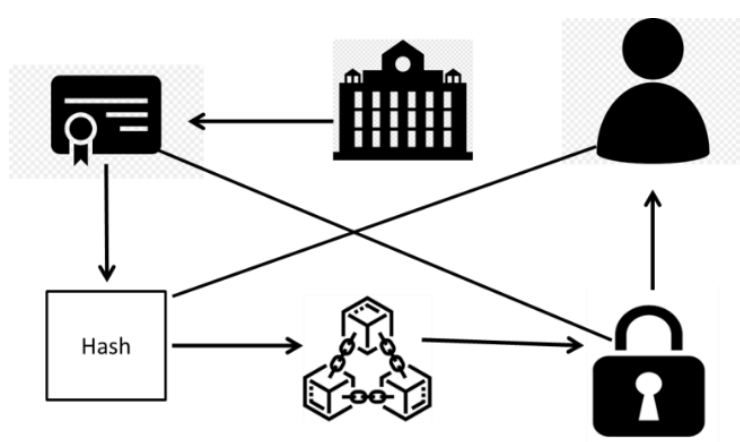

Fig. 6. Blockchain in Certificate

2. Utilization of blockchain technology in the LTAI schedule

Raharja University is one of the educational institutions that utilize blockchain technology in implementing the schedule for conducting LTAI. In the process of making the schedule (schedule) using a programming language (script) using an encryption code (unique) which is the hallmark of blockchain to have strong security, and in the process of making a schedule using Google Calendar.

\section{Blockchain benefits in certificate security}

Security is required in the certificate. Why is that? So that other parties who want to commit fraud by copying the certificate to meet their needs by taking advantage by making the other party feel that the loss will not happen again. Because the certificate already has a code in the form of encryption, the certificate becomes more transparent from the use of blockchain. So that cannot manipulate the certificate with its authenticity maintained, and the stored data is safer with digital storage. If there is damage or loss, the data can still access easily, and it turns out that it can store fingerprints digitally using cryptographic hashes. So, assessments from outside parties can see that the certificate from Raharja University is not fake and of good quality.

\section{CONCLUSIONS}

Blockchain technology is a popular technology that can be applied in universities. It has been used in the application of blockchain-based certification for certificate issuance, blockchain technology in the LTAI schedule, and security in certificates. The research in the paper shows that blockchain has an impact on universities in the existing system from manual to modern. However, there are still shortcomings, such as the method used can use new methods, and it is hoped that this research will provide a big change for further research in the use of blockchain in other fields.

\section{Acknowledgments}

The author expresses his gratitude to Raharja University for providing facilities in the form of a research place to be able to complete this paper on time. The author would like to express his gratitude to Alphabet Incubator, who has provided facilities with financial support free of charge from the initial process of research to completion of the research.

\section{REFERENCES}

[1] U. Rahardja, T. Nurhaeni, A. Khoirunisa, and R. D. I'zzaty, "Ltai Berbasis Teknologi Blockchain Untuk Meningkatkan Alexa Rank," in SENSITIf: Seminar Nasional Sistem Informasi dan Teknologi Informasi, 2019, pp. 373-380. https://www.ejurnal.dipanegara.ac.id/index.php/sensitif/article/view/576

[2] E. Guustaaf, U. Rahardja, Q. Aini, H. W. Maharani, and N. A. Santoso, "Blockchain-based Education Project," Aptisi Trans. Manag., vol. 5, no. 1, pp. 46-61, 2021. https://doi.org/10.33050/atm.v5i1.1433 
[3] N. I. Pratiwi, "Penggunaan Media Video Call Dalam Teknologi Komunikasi,” J. Ilm. Din. Sos., vol. 1, no. 2, pp. 202-224, 2017. https://doi.org/10.38043/jids.v1i2.219

[4] A. Alammary, S. Alhazmi, M. Almasri, and S. Gillani, "Blockchain-based applications in education: A systematic review," Appl. Sci., vol. 9, no. 12, p. 2400, 2019. https://doi.org/10.3390/app9122400

[5] G. Albeanu, "Blockchain technology and education," in The 12th International Conference on Virtual Learning ICVL, 2017, pp. 271-275. https://www.researchgate.net/profile/Snejana-Dineva/publication/327557908

[6] F. J. Oyelere, S. S., Tomczyk, L., Bouali, N., \& Agbo, "Blockchain technology and gamification - conditions and opportunities for education,” Adult Educ. 2018 - Transform. Era Digit. Artif. Intell., no. March, pp. 85-96, 2019, [Online]. Available: https://erepo.uef.fi/handle/123456789/7905

[7] A. I. Irvani, R. Warliani, and R. R. Amarulloh, "Pelatihan Pemanfaatan Teknologi Informasi Komunikasi Sebagai Media Pembelajaran," J. PkM MIFTEK, vol. 1, no. 1, pp. 35-41, 2020. https://doi.org/10.33364/miftek/v.1-1.35

[8] T. Y. Lam and B. Dongol, “A blockchain-enabled e-learning platform," Interact. Learn. Environ., pp. 1-23, 2020. https://doi.org/10.1080/10494820.2020.1716022

[9] E. Akyildirim, S. Corbet, A. Sensoy, and L. Yarovaya, "The impact of blockchain related name changes on corporate performance,” J. Corp. Financ., vol. 65, p. 101759, 2020. https://doi.org/10.1016/j.jcorpfin.2020.101759

[10] C. Turcu, C. Turcu, and I. Chiuchisan, "Blockchain and its Potential in Education," arXiv Prepr. arXiv1903.09300, 2019. https://arxiv.org/abs/1903.09300

[11] P. Bhaskar, C. K. Tiwari, and A. Joshi, "Blockchain in education management: present and future applications," Interact. Technol. Smart Educ., 2020. https://doi.org/10.1108/ITSE-07-2020-0102

[12] C. Li, J. Guo, G. Zhang, Y. Wang, Y. Sun, and R. Bie, "A Blockchain System for E-Learning Assessment and Certification," in 2019 IEEE International Conference on Smart Internet of Things (SmartIoT), 2019, pp. 212-219. https://doi.org/10.1109/SmartIoT.2019.00040

[13] D. F. de Bittencourt, A. R. Goedert, R. C. Sharma, and F. Bortolozzi, "Framework Blockchain Education: Rupture in Higher Education," in Blockchain Technology Applications in Education, IGI Global, 2020, pp. 80-96. https://doi.org/10.4018/978-1-5225-9478-9.ch004

[14] N. Lutfiani, F. P. Oganda, C. Lukita, Q. Aini, and U. Rahardja, "Desain dan Metodologi Teknologi Blockchain Untuk Monitoring Manajemen Rantai Pasokan Makanan yang Terdesentralisasi," InfoTekJar J. Nas. Inform. dan Teknol. Jar., vol. 5, no. 1, pp. 18-25, 2020. https://doi.org/10.30743/infotekjar.v5i1.2517

[15] M. Erna, I. Irfandi, and R. Rasmiwetti, "Development of Learning Media Based on Autoplay Chemistry to Improve Students' Communicative Characters on Chemistry," JTP - J. Teknol. Pendidik., vol. 22, no. 3, pp. 167181, 2021. https://doi.org/10.21009/jtp.v22i3.17823

[16] S. Kolvenbach, R. Ruland, W. Gräther and W. Prinz, "Blockchain 4 Education," Proceedings of 16th European Conference on Computer-Supported Cooperative Work-Panels, Posters and Demos, 2018. https://dl.eusset.eu/handle/20.500.12015/3132

[17] E. Rahmah and M. Marlini, "Millennial Generation Profile: Challenges and Opportunities of Library and Information Science Study Program in Industri Revolution 4.0," in ICLLE 2019: Proceedings of the 2nd International Conference on Language, Literature and Education, ICLLE 2019, 22-23 August, Padang, West Sumatra, Indonesia, 2019, p. 397. https://doi.org/10.4108/eai.19-7-2019.2289493

[18] U. Rahardja, P. A. Sunarya, Q. Aini, and S. R. Dewi, "Solusi Payment Online Berbasis Cloud Accounting Pada Manajemen Perguruan Tinggi," InfoTekJar J. Nas. Inform. dan Teknol. Jar., vol. 3, no. 2, pp. 9-15, 2019. https://doi.org/10.30743/infotekjar.v3i2.779

[19] P. Ocheja, B. Flanagan, and H. Ogata, "Connecting decentralized learning records: a blockchain based learning analytics platform," in Proceedings of the 8th international conference on learning analytics and knowledge, 2018, pp. 265-269. https://doi.org/10.1145/3170358.3170365

[20] U. Rahardja, Q. Aini, M. D. A. Ngadi, M. Hardini, and F. P. Oganda, "The Blockchain Manifesto," in 2020 2nd International Conference on Cybernetics and Intelligent System (ICORIS), 2020, pp. 1-5. https://doi.org/10.1109/ICORIS50180.2020.9320798

[21] J. Guo, C. Li, G. Zhang, Y. Sun, and R. Bie, "Blockchain-enabled digital rights management for multimedia resources of online education," Multimed. Tools Appl., vol. 79, no. 15, pp. 9735-9755, 2020. https://doi.org/10.1007/s11042-019-08059-1

[22] R. Raimundo and A. Rosário, "Blockchain System in the Higher Education," Eur. J. Investig. Heal. Psychol. Educ., vol. 11, no. 1, pp. 276-293, 2021. https://doi.org/10.3390/ejihpe11010021

[23] R. Khalida and S. Setiawati, "Website Technology Trends for Augmented Reality Development," Jurnal Ilmiah Teknik Elektro Komputer dan Informatika, Vol. 6, No. 1, 2020. https://doi.org/10.26555/jiteki.v16i1.16632

[24] M.-F. Steiu, "Blockchain in education: Opportunities, applications, and challenges," First Monday, 2020. https://doi.org/10.5210/fm.v25i9.10654

[25] A. Ramadhani, "Keamanan Informasi," Nusant. - J. Inf. Libr. Stud., vol. 1, no. 1, p. 39, 2018. https://doi.org/10.30999/n-jils.v1i1.249

[26] N. S. Widodo and A. Pamungkas, "Machine Vision-based Obstacle Avoidance for Mobile Robot," JITEKI (Jurnal Ilm. Tek. Elektro Komput. dan Inform., 2019. https://doi.org/10.26555/jiteki.v5i2.14767

[27] G. Chen, B. Xu, M. Lu, and N.-S. Chen, "Exploring blockchain technology and its potential applications for education," Smart Learn. Environ., vol. 5, no. 1, pp. 1-10, 2018. https://doi.org/10.1186/s40561-017-0050-x

[28] A. Bozkurt and H. Ucar, "Blockchain Technology as a Bridging Infrastructure Among Formal, Non-Formal, and Informal Learning Processes," in Research Anthology on Adult Education and the Development of Lifelong 
Learners, IGI Global, 2021, pp. 959-970. https://doi.org/10.4018/978-1-7998-8598-6.ch047

[29] R. Hanifatunnisa and M. Ismail, "Desain dan Implementasi Sistem Pencatatan Pemungutan Suara dengan Teknologi Blockchain pada Jaringan Peer-to-Peer," J. Nas. Tek. Elektro dan Teknol. Inf., vol. 9, no. 4, pp. 354 364. https://doi.org/10.22146/jnteti.v9i4.648

[30] A. Mikroyannidis, A. Third, J. Domingue, M. Bachler, and K. A. Quick, "Blockchain applications in lifelong learning and the role of the semantic blockchain," in Blockchain Technology Applications in Education, IGI Global, 2020, pp. 16-41. https://doi.org/10.4018/978-1-5225-9478-9.ch002

[31] J. C. Ewald, S. Reich, S. Baumann, W. B. Frommer, and N. Zamboni, "Engineering genetically encoded nanosensors for real-time in vivo measurements of citrate concentrations," PLoS One, vol. 6, no. 12, p. e28245, 2011. https://doi.org/10.1371/journal.pone.0028245

[32] I. B. P. Bhiantara, "Teknologi Blockchain Cryptocurrency Di Era Revolusi Digital," in Seminar Nasional Pendidikan Teknik Informatika (SENAPATI), 2018, vol. 9, pp. 173-177.

[33] H. Haugsbakken and I. Langseth, "The blockchain challenge for higher education institutions," Eur. J. Educ., vol. 2, no. 3, pp. 41-46, 2019. https://doi.org/10.26417/ejed.v2i3.p41-46

[34] N. Gajendran, "Blockchain-Based secure framework for elearning during COVID-19," Indian J. Sci. Technol., vol. 13, no. 12, pp. 1328-1341, 2020. https://doi.org/10.17485/IJST/v13i12.152

[35] M. Han, Z. Li, J. He, D. Wu, Y. Xie, and A. Baba, "A novel blockchain-based education records verification solution," in Proceedings of the 19th Annual SIG Conference on Information Technology Education, 2018, pp. 178-183. https://doi.org/10.1145/3241815.3241870

[36] S. S. Oyelere, L. Tomczyk, N. Bouali, and F. J. Agbo, "Blockchain technology and gamification-conditions and opportunities for education," Adult Educ. 2018-Transformation Era Digit. Artif. Intell., 2019. https://erepo.uef.fi/handle/123456789/7905

[37] F. P. Oganda, U. Rahardja, Q. Aini, M. Hardini, and A. S. Bist, "Blockchain: Visualization Of The Bitcoin Formula," PalArch's J. Archaeol. Egypt/Egyptology, vol. 17, no. 6, pp. 308-321, 2020.

[38] M. D. K. Perdani, W. Widyawan, and P. I. Santosa, "Blockchain untuk Keamanan Transaksi Elektronik Perusahaan Financial Technology (Studi Kasus pada PT XYZ)," Semnasteknomedia Online, vol. 6, no. 1, pp. 1-14, 2018. https://ojs.amikom.ac.id/index.php/semnasteknomedia/article/view/2132

[39] D. Shah, D. Patel, J. Adesara, P. Hingu, and M. Shah, "Exploiting the Capabilities of Blockchain and Machine Learning in Education," Augment. Hum. Res., vol. 6, no. 1, pp. 1-14, 2021. https://doi.org/10.1007/s41133-02000039-7

[40] F. Agustin, F. P. Oganda, N. Lutfiani, and E. P. Harahap, "Manajemen Pembelajaran Daring Menggunakan Education Smart Courses," TMJ (Technomedia Journal) Vol. 5 No. 1 Agustus 2020, p. 40, 2021. https://doi.org/10.33050/tmj.v5i1.1315

[41] S. Kosasi, "Karakteristik Blockchain Teknologi Dalam Pengembangan Edukasi," ADI Bisnis Digit. Interdisiplin J., vol. 1, no. 1, pp. 87-94, 2020. https://doi.org/10.34306/abdi.v1i1.113

[42] K. Kuvshinov, I. Nikiforov, J. Mostovoy, D. Mukhutdinov, K. Andreev, and V. Podtelkin, "Disciplina: Blockchain for education," Yellow Pap. URL: https//disciplina. io/yellowpaper.pdf, 2018. https://www.disciplina.io/yellowpaper.pdf

[43] D. A. Filvà, F. J. García-Peñalvo, M. A. Forment, D. F. Escudero, and M. J. Casañ, "Privacy and identity management in Learning Analytics processes with Blockchain," in Proceedings of the Sixth International Conference on Technological Ecosystems for Enhancing Multiculturality, 2018, pp. 997-1003. https://doi.org/10.1145/3284179.3284354

[44] A. Winarno, "Desain E-Transkrip dengan Teknologi Blockchain," in Prosiding Seminar Nasional Pakar, 2019, pp. 1-37. https://trijurnal.lemlit.trisakti.ac.id/pakar/article/view/4176

[45] M. Ortiz-Rojas, K. Chiluiza, and M. Valcke, "Gamification through leaderboards: An empirical study in engineering education," Comput. Appl. Eng. Educ., vol. 27, no. 4, pp. 777-788, 2019. https://doi.org/10.1002/cae.12116

[46] Q. Aini, U. Rahardja, N. P. L. Santoso, and A. Oktariyani, "Aplikasi Berbasis Blockchain dalam Dunia Pendidikan dengan Metode Systematics Review,” CESS (Journal Comput. Eng. Syst. Sci., vol. 6, no. 1, pp. 58-66, 2021. https://doi.org/10.24114/cess.v6i1.20107

[47] A. Widiansyah, "Peranan Sumber Daya Pendidikan sebagai Faktor Penentu dalam Manajemen Sistem Pendidikan," Cakrawala-Jurnal Hum., vol. 18, no. 2, pp. 229-234, 2018. https://doi.org/10.24252/idaarah.v2i2.6864

[48] A. Argani and W. Taraka, "Pemanfaatan Teknologi Blockchain Untuk Mengoptimalkan Keamanan Sertifikat Pada Perguruan Tinggi," ADI Bisnis Digit. Interdisiplin J., vol. 1, no. 1, pp. 10-21, 2020. https://doi.org/10.34306/abdi.v1i1.121

[49] M. E. Parra-González, J. L. Belmonte, A. Segura-Robles, and A. F. Cabrera, "Active and emerging methodologies for ubiquitous education: Potentials of flipped learning and gamification," Sustain., vol. 12, no. 2, 2020. https://doi.org/10.3390/su12020602

[50] M. F. Azima, "Teknologi Informasi E-Complaint pada Perguruan Tinggi," J. Inform., vol. 18, no. 2, pp. 116-123, 2018. https://jurnal.darmajaya.ac.id/index.php/JurnalInformatika/article/view/1322

[51] M. Yusup, Q. Aini, D. Apriani, and P. Nursaputri, "Pemanfaatan Teknologi Blockchain Pada Program Sertifikasi Dosen," in SENSITIf: Seminar Nasional Sistem Informasi dan Teknologi Informasi, 2019, pp. 365-371. https://www.ejurnal.dipanegara.ac.id/index.php/sensitif/article/view/575

[52] H. Sun, X. Wang, and X. Wang, "Application of blockchain technology in online education," Int. J. Emerg. Technol. Learn., vol. 13, no. 10, pp. 252-259, 2018. https://doi.org/10.3991/ijet.v13i10.9455 
[53] I. A. Huda, "Perkembangan Teknologi Informasi dan Komunikasi (TIK) Terhadap Kualitas Pembelajaran di Sekolah Dasar," J. Pendidik. dan Konseling, vol. 1, no. 2, pp. 143-149, 2020. https://doi.org/10.31004/jpdk.v1i2.622

[54] C. Lukita, "Penerapan Sistem Pendataan Hak Cipta Content Menggunakan Blockchain," ADI Bisnis Digit. Interdisiplin J., vol. 1, no. 2 Desember, pp. 40-45, 2020. https://doi.org/10.34306/abdi.v1i2.120

[55] M. Husaini, "Pemanfaatan teknologi informasi dalam bidang pendidikan (e-education)," MIKROTIK J. Manaj. Inform., vol. 2, no. 1, 2017. https://ojs.ummetro.ac.id/index.php/mikrotik/article/view/314

[56] S. H. Aji and Suparno, "Increasing HOTS of High School Students Using Mobile Technology and Scaffolding Approach: Study on Physics Learning," JTP - J. Teknol. Pendidik., vol. 22, no. 3, pp. 182-199, 2021. https://doi.org/10.21009/jtp.v22i3.17845

[57] Q. Aini, U. Rahardja, and A. Khoirunisa, "Blockchain Technology into Gamification on Education," IJCCS (Indonesian J. Comput. Cybern. Syst., vol. 14, no. 2, p. 147, 2020. https://doi.org/10.22146/ijccs.53221

[58] A. C. Nugraha, "Penerapan Teknologi Blockchain dalam Lingkungan Pendidikan: Studi Kasus Jurusan Teknik Komputer dan Informatika POLBAN," Produktif J. Ilm. Pendidik. Teknol. Inf., vol. 4, no. 1, pp. 15-20, 2020. http://umtas.ac.id/journal/index.php/produktif/article/view/386

[59] Q. Aini, U. Rahardja, and A. Khoirunisa, "Blockchain Technology into Gamification on Education," IJCCS (Indonesian J. Comput. Cybern. Syst., vol. 14, no. 2, pp. 147-158, 2020. https://doi.org/10.22146/ijccs.53221

[60] M. Khalil, J. Wong, B. De Koning, M. Ebner, and F. Paas, "Gamification in MOOCs: A review of the state of the art," IEEE Glob. Eng. Educ. Conf. EDUCON, vol. 2018-April, pp. 1629-1638, 2018. https://doi.org/10.1109/EDUCON.2018.8363430

\section{BIOGRAPHY OF AUTHORS}

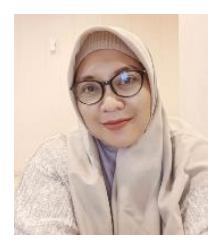

Riya Widayanti is a lecturer at esa superior university with an information systems study program Email: riya.widayanti@esaunggul.ac.id

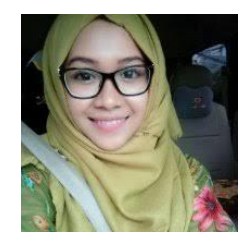

Eka Purnama Harahap is a lecturer from Raharja University with a major in informatics engineering. Email: ekapurnamaharahap@raharja.info

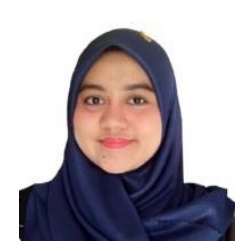

Ninda Lutfiani is a lecturer from Raharja University with a field of knowledge in information systems. Email: ninda@raharja.info

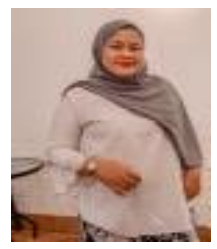

Fitra Putri Oganda is continuing her postgraduate education at the Master of Informatics Engineering at Raharja University in 2021. Email: fitra.putri@ raharja.info

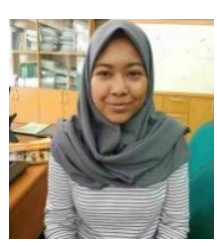

Ita Sari Perbina Manik is a student of Raharja University with a major in Information Systems. Email: ita.sari@raharja.info 